\title{
Study On Buffering Capacity And Organic Matter Of Some Soil Samples From Rungicherra Tea-Estate, Bangladesh
}

\author{
Rausan Zamir ${ }^{1, a^{*}}$, Nazmul Islam ${ }^{2, b}$, M. F. Hossain ${ }^{3, ~ c ~}$ \\ 1, 2 \& 3 Department of Natural Sciences, Daffodil International University, Dhaka- 1207, Bangladesh \\ E-mail address: ${ }^{a}$ rsnzamir@yahoo.com, ${ }^{b}$ nazmul..acce.26@gmail.com, \\ cdrfokhray@daffodilvarsity.edu.bd
}

Keywords: Buffer capacity, organic matter, soil samples and topographical positions.

\begin{abstract}
In this study, soil samples from three different hills of three topographic positions were evaluated on the basis of buffer capacity and organic matter. Maximum soil samples were found to have good buffer capacity where soil samples of topographical positions hill base and hill top showed maximum and minimum values respectively, leaving hill slope samples in medium value of buffer capacity. Our study suggested this variation of buffer capacity may be due to the differences of organic matter amongst the topographical positions and profiles.
\end{abstract}

\section{INTRODUCTION}

Buffer capacity of soil, an important parameter which controls the active acidity and reserse acidity of soil, is defined as a soil's ability to maintain a constant $\mathrm{pH}$ level [1] during action on it by an acidifier or alkalescent agent. The buffer capacity is often quoted as a single value for a particular soil, implying a linear relationship between $\mathrm{pH}$ and the amount of acid or alkali added [2]. A soil, considered a mixture of buffered systems, contains components, which have the ability to neutralize acids by bonding $\mathrm{H}^{+}$ions as well as bases by the release of hydrogen ions [3]. The effectiveness of soil buffering systems depends on numerous physical, chemical, and biological properties of soils [4]- [5]. Soil buffer capacity, measured using titration techniques that produce a $\mathrm{pH}$ buffer curve [6]- [13]. The buffering capacity directly related to the cation exchange capacity which shows how well a soil can hold onto and store cations, so a soil with a high cation exchange capacity would be able to hold more nutrients. A soil with low cation exchange capacity would not only be missing some important nutrients but would also not be able to hold onto nutrients as well as a soil with a higher cation exchange capacity.

The availability of different functional groups (e.g. carboxylic, phenolic, acidic, alcoholic, amine, amide) allows soil organic matter to buffer over a wide range of soil $\mathrm{pH}$ values [14], demonstrate the dependence of $\mathrm{pH}$ buffer capacity from soil type and organic matter and type of added.

\section{MATERIALS AND METHOD}

\section{A. Field Sampling}

Soil samples were collected from Rungicherra Tea-Estate which is located in Moulovibazar, a district of Sylhet Division in North-Eastern Bangladesh where each hill was divided into three parts, namely, hill top, hill slope and hill base. Equal amount of soils of four different points having an approximate area of $2500 \mathrm{sq}$. meter of any of the parts stated above were mixed thoroughly to make a representative soil sample of that layer.

\section{B. Laboratory Method}

Soil samples were dried in the air under room temperature after removing roots and stones, crushed and passed through 325 mesh sieves. $10 \mathrm{gm}$ of the soil sample was placed in each of the two $50 \mathrm{ml}$ beaker and $25 \mathrm{ml}$ distilled water was added with constant stirring. Into one of the soil 
suspension $0.01 \mathrm{~N} \mathrm{NaOH}$ was added with $0.5 \mathrm{ml}$ increments. To the other soil sample $0.01 \mathrm{~N} \mathrm{HCl}$ was added with $0.5 \mathrm{ml}$ increments. Initial and final $\mathrm{pH}$ was measured for both samples.

\section{Soil Organic Matter}

$2.0 \mathrm{gm}$ oven dried soil was taken in a clean, dry $500-\mathrm{ml} 250 \mathrm{ml}$ conical flask. $10 \mathrm{ml} 1 \mathrm{~N}$ $\mathrm{K}_{2} \mathrm{Cr}_{2} \mathrm{O}_{7}$ solution and $10 \mathrm{ml}$ conc. $\mathrm{H}_{2} \mathrm{~S}_{4}$ were added to it. If the suspension became greenish further $5 \mathrm{ml} 1 \mathrm{~N} \mathrm{~K}_{2} \mathrm{Cr}_{2} \mathrm{O}_{7}$ was poured. The contents were occasionally shaken and cooled for half an hour. Then $150 \mathrm{ml}$ distilled water was added. After cooling 5-ml conc. $\mathrm{H}_{3} \mathrm{PO}_{4}$ and about 0.5 gm NaF were added. Diphenylamine indicator was added dropwise until the color of the solution became deep violate. This was then titrated against $1 \mathrm{~N}$ ferrous sulfate solution. At the end point the color changes to bottle green. A blank without soil was also done [15]- [17].

$$
\% \text { Organic Carbon }=\frac{(B-T) * F(0.3)}{W}
$$

\section{Where,}

$\mathrm{B}=$ Blank titration reading $(\mathrm{ml})$

$\mathrm{T}=$ Soil titration reading $(\mathrm{ml})$

$\mathrm{F}=$ Strength of ferrous sulfate and

$\mathrm{W}=$ Weight of soil $(\mathrm{g})$

$$
\% \text { Organic matter }=\% \text { Organic carbon } \times 1.7
$$

\section{RESULTS \& DISCUSSION}

From the tables 2-4 the values of buffer capacity varied with tillah to tillah as well as with the topographic positions and soil depths in the same tillah. In fig- 1(a), by the addition of $\mathrm{NaOH}$, hill top is found to have lowest increase in $\mathrm{pH}$ and in fig- 1(b), by the addition of $\mathrm{NaOH}$, hill top is found to have lowest decrease in $\mathrm{pH}$, indicating best performing buffer capacity for the sample, whereas highest change in $\mathrm{pH}$ was observed in sample collected from hill base, leaving the soil of hill base lowest performing buffer.

Same variation is observed in all the depths under consideration (0-9 inch, 9- 18 inch and 1836 inch). Hill- 02, and Hill- 03 were mimicking Hill- 01 as buffer capacity of hill top were also showing best performance, leaving poor performance of hill base samples which were emerging in fig- 2(a), 2(b) and fig- 3(a), 3(b).

In summing, the variation followed a sequence for the studied area is Hill-Top $>$ HillSlope $>$ Hill-Base. This sequence may be due to difference of organic carbon amongst the topographic positions and profiles as the value of organic matter in hill no 01 , hill top has found to contain maximum organic matter with hill base was found containing minimum organic matter table- 01 . Hill 02 and hill 03 were found mimicking hill 01 and same sequence in containing organic matter were observed when going through depth of 0-9 inch, 9-18 inch and 18- 36 inch in all the hills and topographical positions under consideration. 

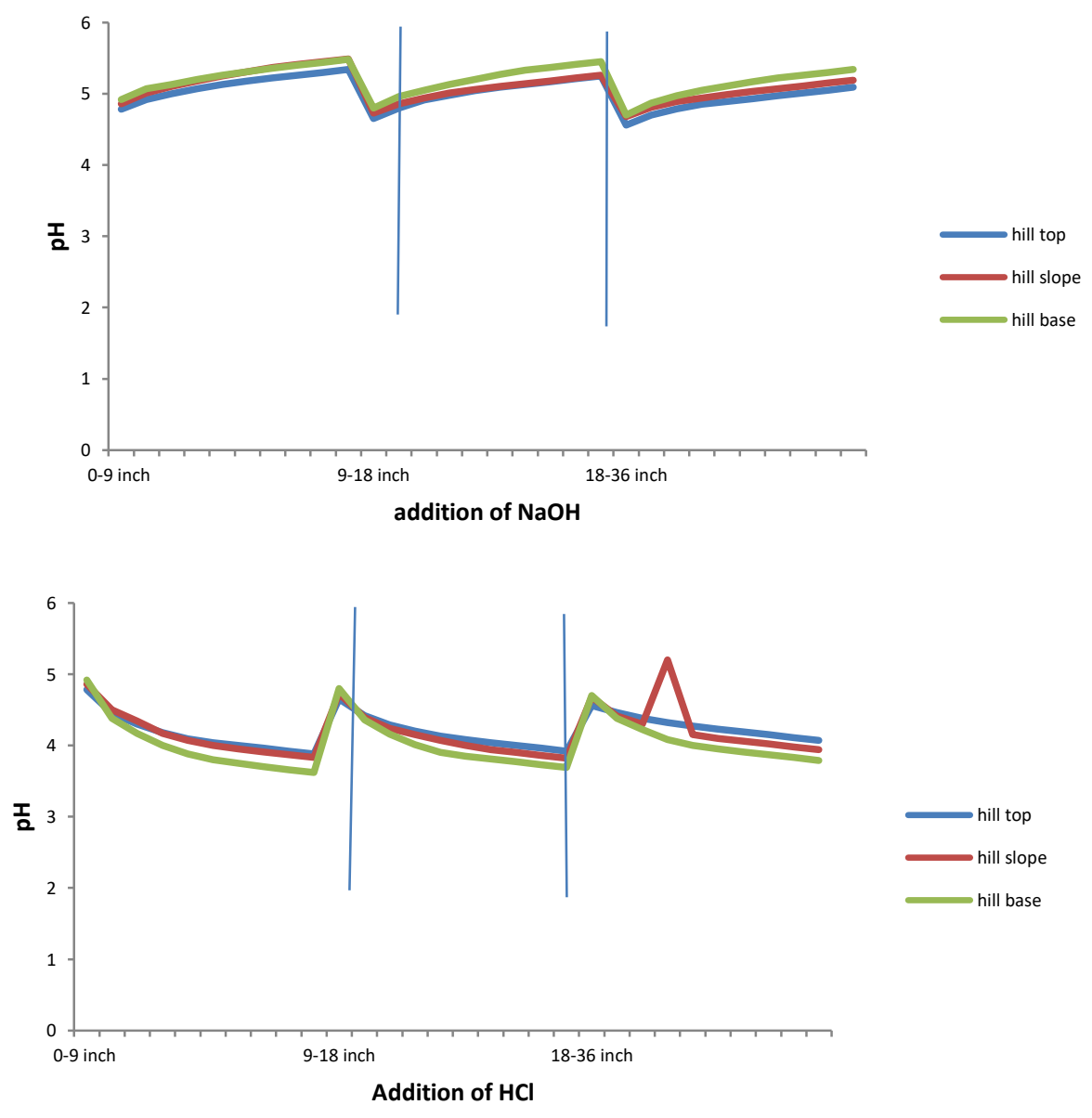

Figure 1(a) \& 1 (b): buffer capacity of Hill no 1

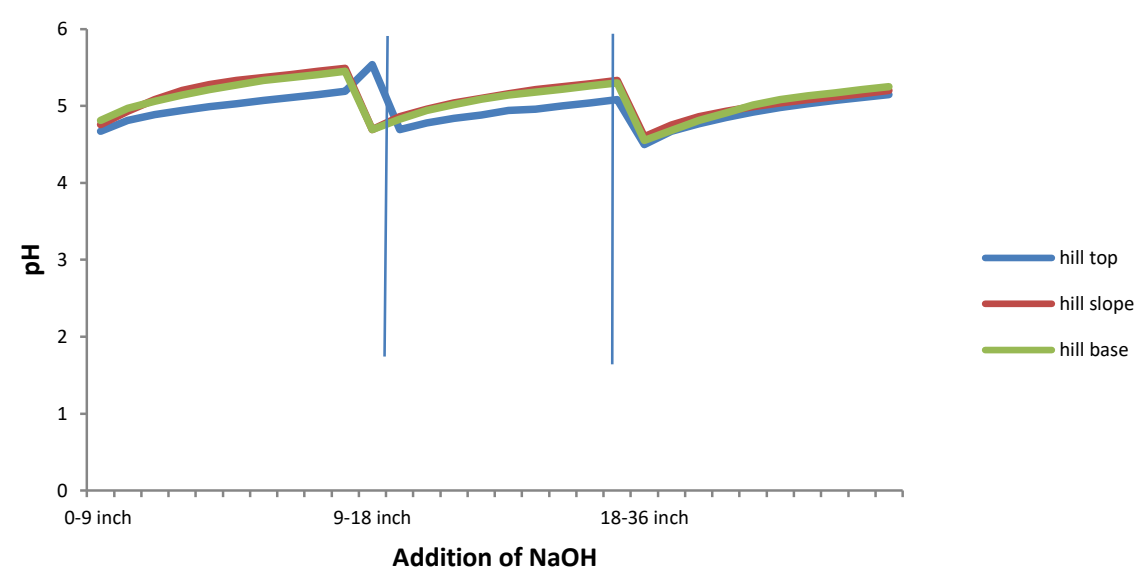




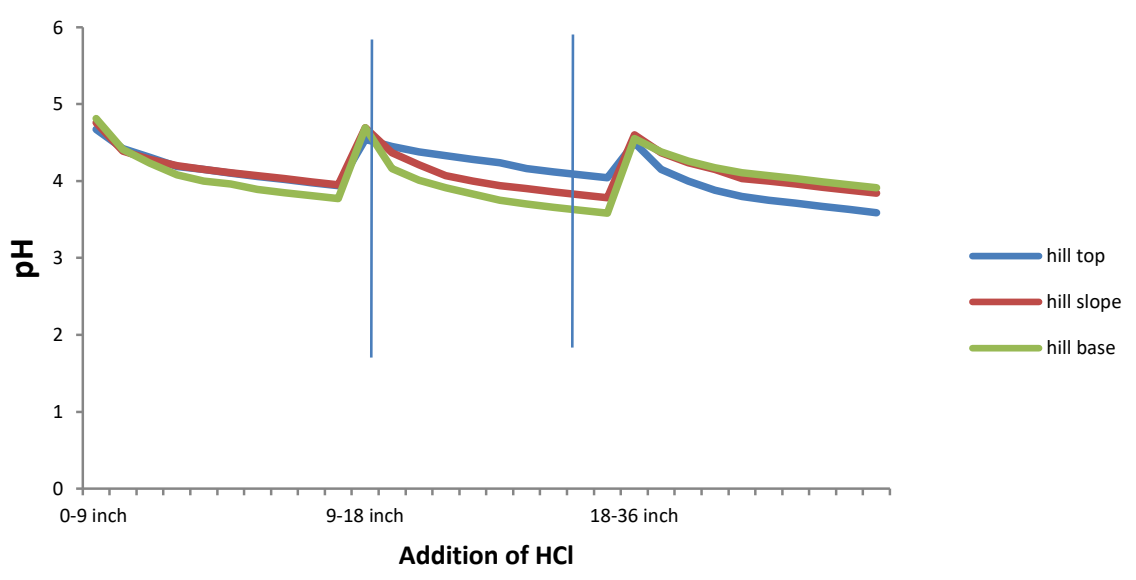

Figure 2(a) \& 2 (b): buffer capacity of Hill no2

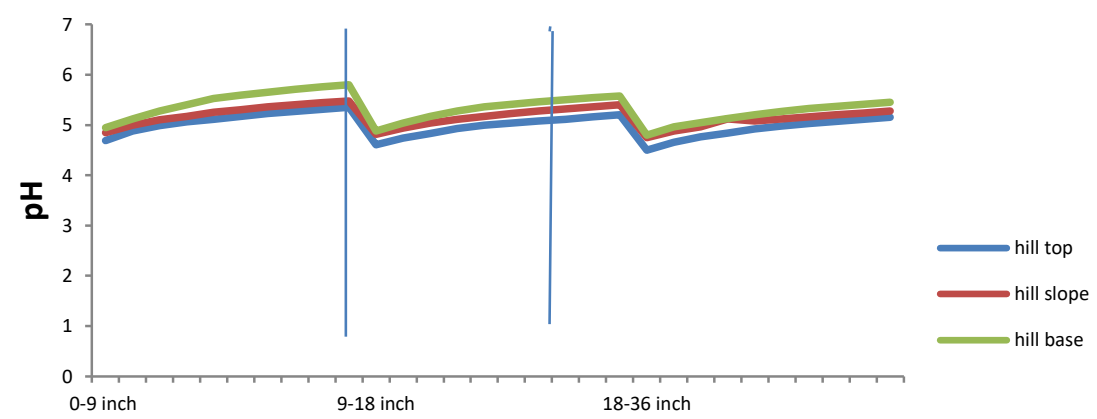

Addition of $\mathrm{NaOH}$

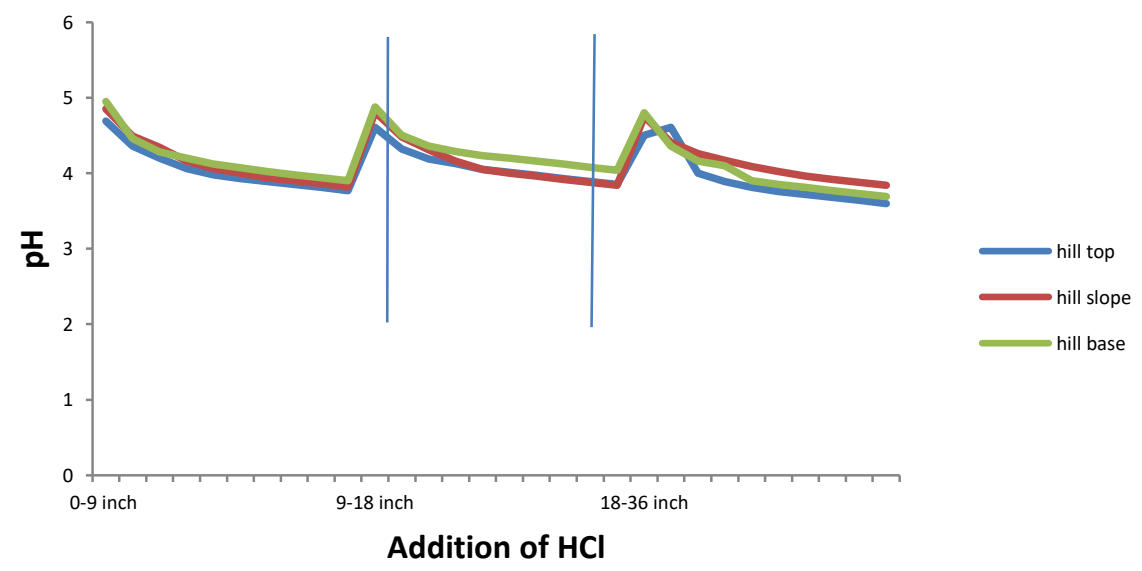

Figure 3(a) \& 3 (b): buffer capacity of Hill no 3 
TABLE- I

ORGANIC CARBON AND ORGANIC MATTER CONTENT IN HILLS IN RUNGICHERRA TEA-ESTATE, BANGLADESH

\begin{tabular}{|c|c|c|c|c|c|c|c|}
\hline \multirow{2}{*}{$\begin{array}{l}\text { Hill } \\
\text { No }\end{array}$} & \multirow{2}{*}{$\begin{array}{l}\text { Topographical } \\
\text { positions }\end{array}$} & \multicolumn{3}{|c|}{ Organic carbon \% } & \multicolumn{3}{|c|}{ Organic matter \% } \\
\hline & & $\begin{array}{c}\text { 0-9 inch } \\
\text { depth }\end{array}$ & $\begin{array}{l}\text { 9-18 inch } \\
\text { depth }\end{array}$ & $\begin{array}{c}\text { 18-36 } \\
\text { inch } \\
\text { depth }\end{array}$ & $\begin{array}{c}\text { 0-9 inch } \\
\text { depth }\end{array}$ & $\begin{array}{l}\text { 9-18 inch } \\
\text { depth }\end{array}$ & $\begin{array}{c}18-36 \\
\text { inch } \\
\text { depth }\end{array}$ \\
\hline \multirow{3}{*}{$\mathbf{I}$} & Hill Top & 1.039 & 0.921 & 0.932 & 1.787 & 1.584 & 1.603 \\
\hline & Hill Slope & 0.962 & 0.673 & 0.901 & 1.655 & 1.157 & 1.598 \\
\hline & Hill Base & 0.854 & 0.433 & 0.796 & 1.469 & 0.745 & 1.369 \\
\hline \multirow{3}{*}{ II } & Hill Top & 1.121 & 1.039 & 1.033 & 1.928 & 1.787 & 1.777 \\
\hline & Hill Slope & 0.951 & 0.953 & 0.901 & 1.636 & 1.639 & 1.450 \\
\hline & Hill Base & 0.872 & 0.835 & 0.762 & 1.501 & 1.436 & 1.311 \\
\hline \multirow{3}{*}{ III } & Hill Top & 1.531 & 1.195 & 1.021 & 2.633 & 2.055 & 1.756 \\
\hline & Hill Slope & 1.399 & 1.134 & 0.853 & 2.406 & 1.950 & 1.467 \\
\hline & Hill Base & 1.202 & 1.053 & 0.702 & 2.067 & 1.811 & 1.207 \\
\hline
\end{tabular}

\section{CONCLUSION}

From the buffer capacity data of the soil samples (Tables, 1-3) and their corresponding graphical representation compared with a reagent blank, (Fig: 1-4) it is evident, the buffer capacity varied slightly with topographic positions and with soil depth. This variation of buffer capacity might be due to difference of organic carbon amongst the topographic positions and profiles as the value of organic matter content in the soil of Rimgicherra Tea-Estate, showing a decreasing manner with increasing buffer capacity.

TABLE- 2

BUFFER CAPACITY OF HILL NO 01 IN RUNGICHERRA TEA-ESTATE, BANGLADESH

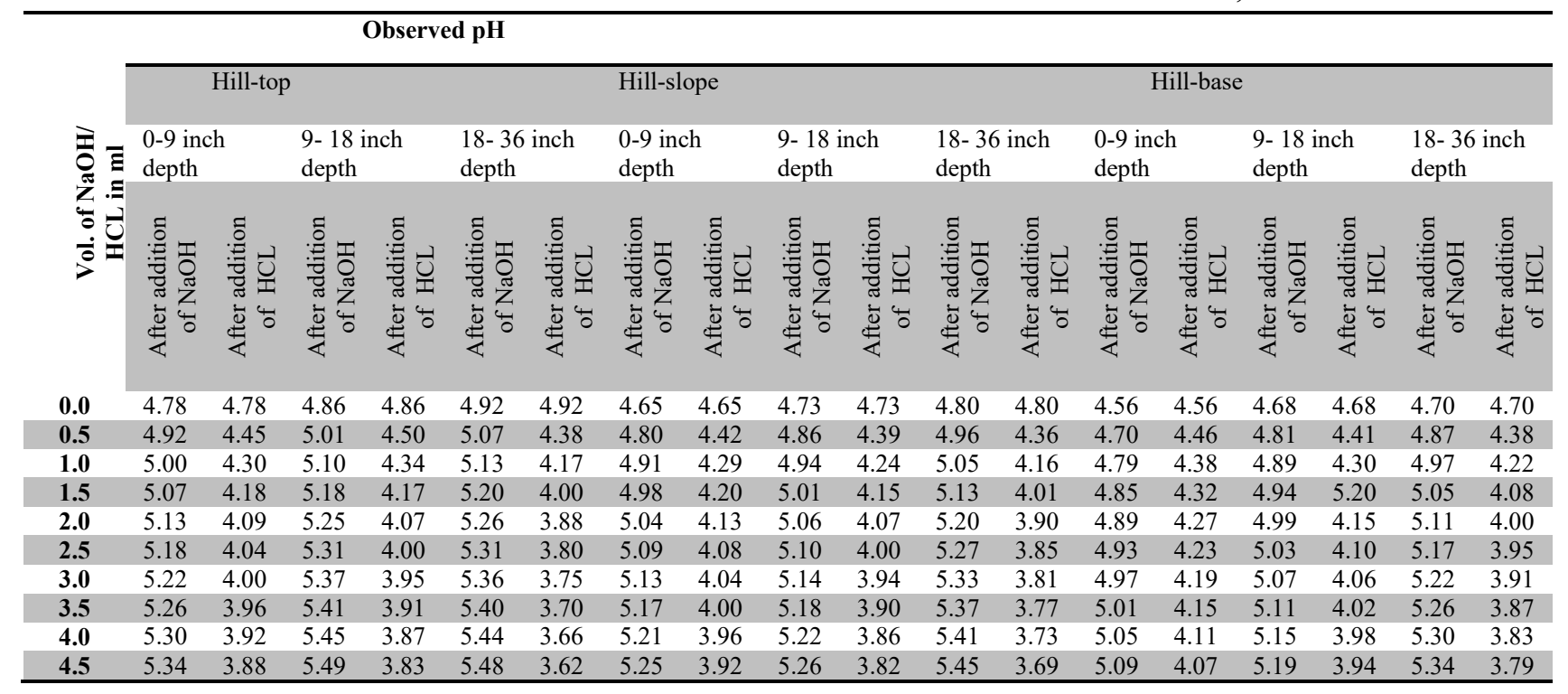


TABLE- 3

BUFFER CAPACITY OF HILL NO 02 IN RUNGICHERRA TEA-ESTATE, BANGLADESH

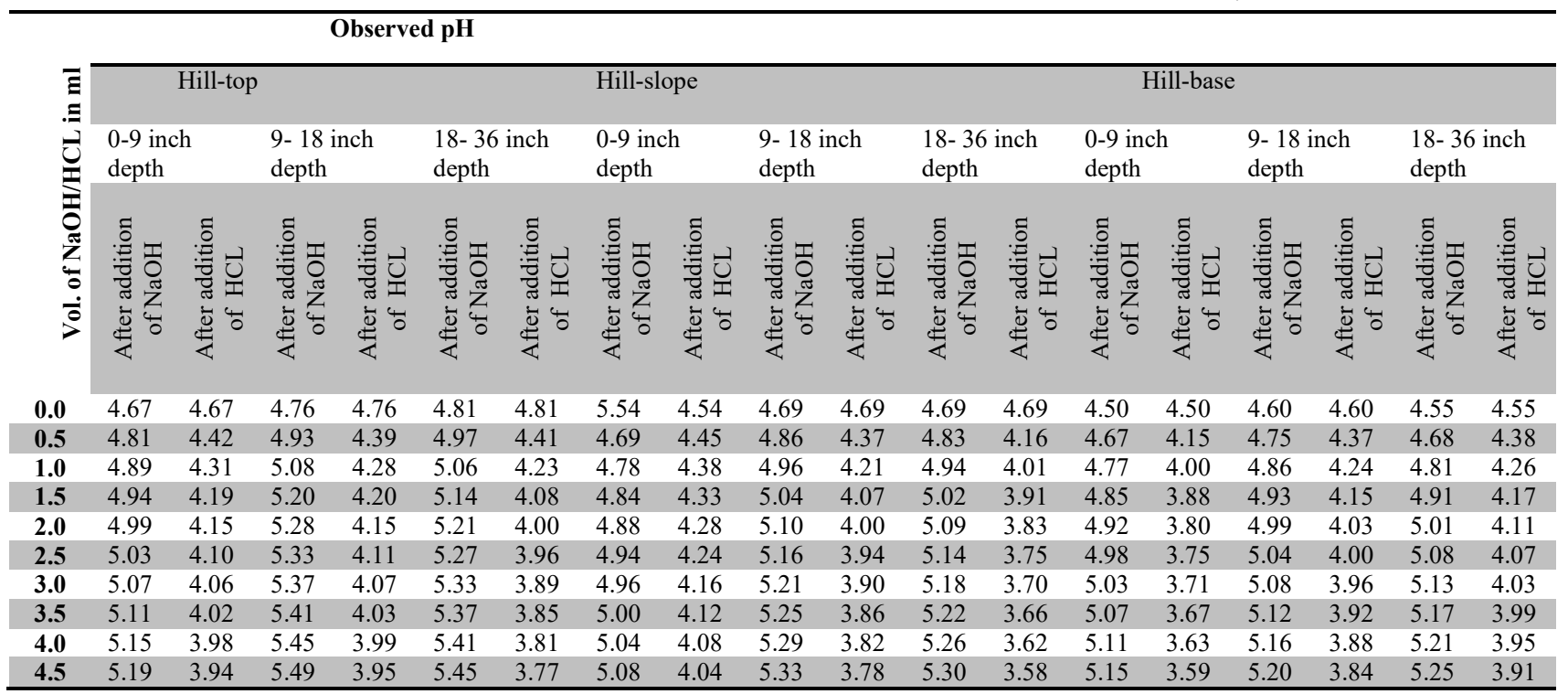

TABLE- 4

BUFFER CAPACITY OF HILL NO 03 IN RUNGICHERRA TEA-ESTATE, BANGLADESH

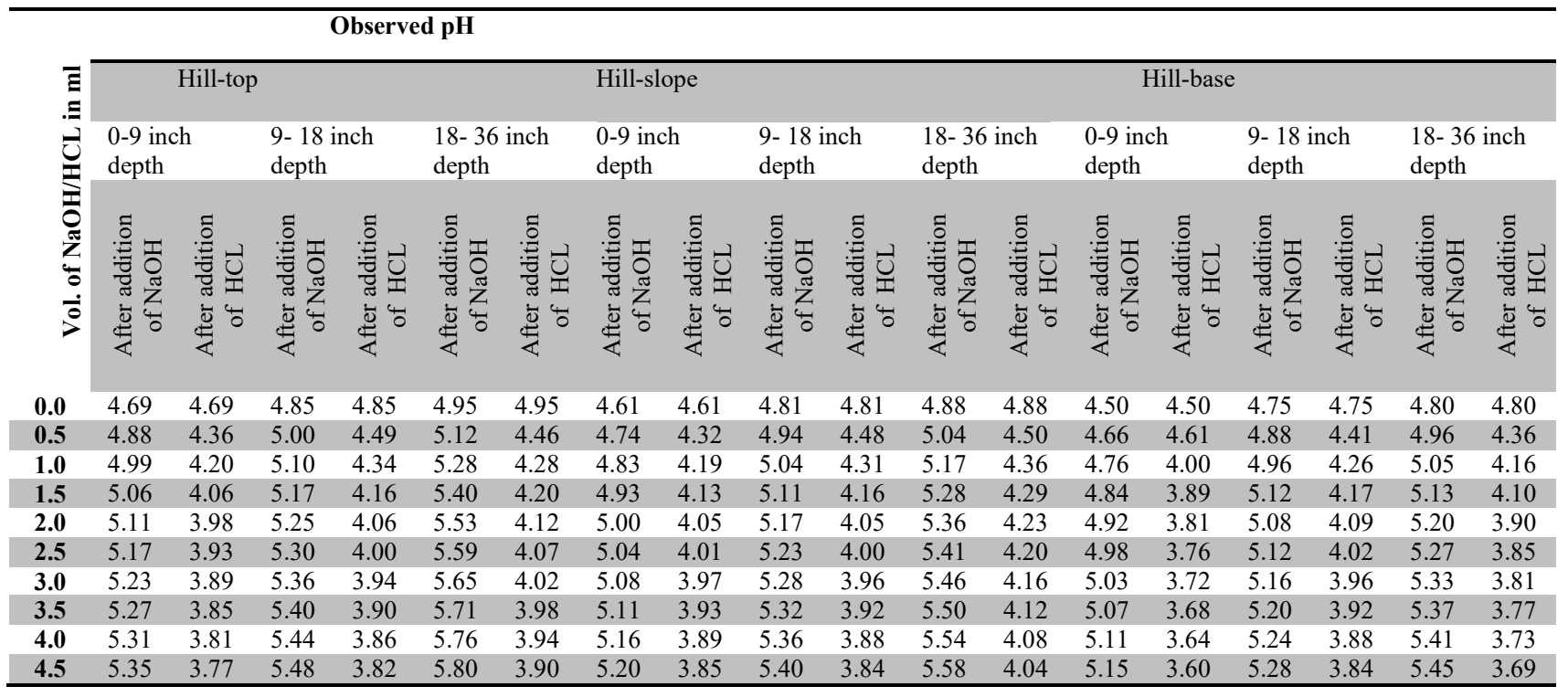

\section{References}

[1] K. A. Armson, "Forest soils: Properties and processes", Toronto: University of Toronto Press, 1977.

[2] N. Paul, Su. Nelson and Ninghu, , "Soil pH buffering capacity: a descriptive function and its application to some acidic tropical soils", Australian Journal of Soil Research, 48(2010) 201-207

[3] Federer, C.A., Hornbeck, J.W., The buffer capacity of forest soils in New England. Water, Air and Soil Pollution, 26 (1985) 163-173

[4] Forro, E., Csomo, Z., Organic matter content and acidic-alkalic buffer capacity of forest soils. Controlling N flows and losses. The 12 th N Workshop, 21-24. September 2003, Exeter, Devon, United Kingdom, 2003 
[5] Csoma, Z. , Forro, E., Changes of soil properties influencing ecosystem tolerance in different forest development phases. E cology. Person. Society. V Inter- national Scientific and Practical Students', Postgr aduates', Young scientists' Conference, Kyiv, Ukraine 182-183. , 2002

[6] Helyar, K.R., Porter, W.M., Soil acidification, its measurement and the processes involved. In 'Soil acidity and plant growth'. (Ed. AD Robson) 61-101. (Academic Press: Sydney, 1989

[7] Ahern, C., Weinand, M., Eldershaw, V., Soil pH and acidification risk in non-arid Queensland. Australian Journal of Soil and Water Conservation, 6 (1993) 44-49,

[8] Dolling, P.J., Porter, W.M., Acidification rates in the central wheatbelt of Western Australia. On a deep yellow sand. Australian Journal of Experimental Agriculture, 34 (1994) 1155-1164,

[9] Dolling, P.J., Porter, W.M., Rowland, I.C., Acidification rates in the central wheatbelt of Western Australia. On a sandy duplex soil. Australian Journal of Experimental Agriculture, 34(1994) 1165-1172.

[10] Dolling, P.J., Effect of lupins and location on soil acidification rates. Australian Journal of Experimental Agriculture, 35 (1995) 753-763.

[11] Porter, W.M., McLay, C.D.A., Dolling, P.J., Rates and sources of acidification in agricultural systems of southern Australia. In 'Plant-soil interactions at low pH, pp. 75-83. Kluwer Academic Publishers: Dordrecht, The Netherlands, 1995

[12] Moody, P.W., Aitken, R.L., Soil acidification under some tropical agricultural systems. 1. Rates of acidification and contributing factors. Australian Journal of Soil Research, 35 (1997) 163173 ,

[13] Lesturgez, G., Poss, R., Noble, A., Grünberger, O., Chintachao, W., Tessier, D., Soil acidification without $\mathrm{pH}$ drop under intensive cropping systems in Northeast Thailand. Agriculture, Ecosystems \& Environment, 114 (2006) 239-248

[14] Krull, E. S., Skjemstad, J.O., Baldock, J.A., Functions of Soil Organic Matter and the Effect on Soil Properties, 2004

[15] Nelson, D.W., and Sommers, L.E., Total carbon, organic carbon, and organic matter, in Sparks, D.L. et al. (Eds.). Methods of Soil Analysis, Part 3. Chemical Methods, Soil Science Society of America Inc., Madison, Wisc, 961-1010 (1996)

[16] Walkley, A., and Black, L.A., An examination of the Degtjareff method for determining soil organic matter and a proposed modification of the chromic acid titration method. Soil Sci. 37 (1934) 29-38.

[17] Jackson, M.L., Soil Chemical Analysis, Prentice-Hall, Inc., Englewood Cliffs, NJ, 1958. 